\title{
Triagem por poliéteres ionóforos em linhagens de Streptomyces endofíticas
}

\author{
Gabriel Ap. M. e Silva*, Bruno S. Paulo, Luciana G. de Oliveira
}

\section{Resumo}

Atualmente um grande número de drogas comerciais são baseados ou inspirados em produtos naturais, e devido a grande demanada existe grande interesse na produção e identifição de novos produtos. Dentre os produtos naturais de maior aplicação se destacam os policetídeos complexos e os peptideos não-ribossomais. Esses compostos são metabólitos de organismos como bactérias, fungos, insetos etc. Em particular, actinobactérias do gênero Streptomyces são reconhecidamente promissoras na produção de metabólitos com atividade farmacológica e de facil manipulação. Nesse contexto esse projeto se baseia na triagm por linhagens de Streptomyces produtoras de poliéteres ionóforos (produto natural policetídico) utilizando-se provas metabólicas.

\section{Palavras-chave: Produtos naturais; poliéteres ionóforos; Streptomyces}

\section{Introdução}

Streptomyces albus é uma linhagem conhecida pela produção do poliéter ionóforo salinomicina cuja biossíntese é promovida por enzimas multifuncionais conhecidas como policetídeo sintase (PKSs) ${ }^{1}$. Uma enzima da classe das monooxigenases dependentes de flavina (FMN) e que catalisa a etapa de oxidação da cadeia poli-insaturada crescente possui regiões altamente conservadas no DNA que as codificam e a partir dessa informação é possível conceber provas metabólicas para a triagem de poliéteres ionóforos a partir do genoma de Streptomyces. Utilizando-se a reação em cadeia da polimerase (PCR) com primers específicos foi possível realizar uma triagem de linhagens de Streptomyces endofíticas na busca por informações codificadas no genoma relacionadas a esse grupo de metabólitos.

\section{Resultados e Discussão}

Inicialmente estabeleceu-se um protocolo promovendose a amplificação do fragmento correspondente ao gene que codifica para a enzima FMN utilizando-se o DNA genômico da linhagem $S$. albus. A linhagem foi cultivada em meio sólido SFM para posterior cultivo em meio líquido TSBY e o DNA genômico foi extraído seguindo protocolo padrão modificado por Sharma e Singh ${ }^{2}$.

Para amplificação da região desejada do DNA genômico foi necessário desenvolver uma condição para o PCR que gerasse um resultado positivo e específico para o tamanho desejado de $0,9 \mathrm{~kb}^{3}$. Foram variados reagentes e otimizados os parâmetros envolvidos em cada etapa da PCR e obteve-se uma condição a qual foi aplicada como padrão para a triagem de 16 linhagens de Streptomyces endofíticas e do solo.

É possível perceber pela fotodocumentação do gel de separação por eletroforese que as linhagens G1, G9 e E1 possuem uma banda de amplificação na região esperada de $0,9 \mathrm{~kb}$ (Figura 1 - $\mathrm{S}$. albus foi utilizada como padrão positivo). As linhagens promissoras G1, G9 e E1 foram então cultivadas em meio vegetativo para crescimento e depois cultivadas em meio específico para fermentação. O meio foi extraído com solvente orgânico e cada linhagem submetida a um teste qualitativo utilizando-se vanilina para indicação da produção de poliéteres ionóforos.

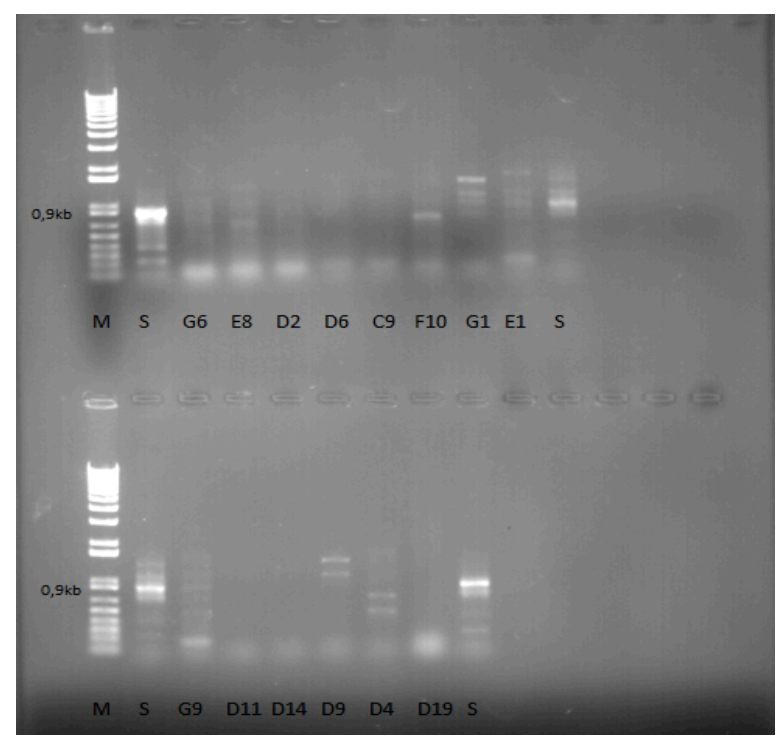

Figura 1: Resultado PCR com 16 linhagens testes e S. albus ( $\mathrm{S}=\mathrm{S}$. albus e $\mathrm{M}=$ Marcador).

As etapas futuras envolvem a avaliação da produção dos ionóforos por espectrometria de massas nos cultivos realizados e sequenciamento das regiões amplificadas por PCR para comparação com $S$. albus e outras linhagens produtoras de ionóforos.

\section{Conclusões}

Depois de diversos testes de PCR em condições diferentes foi encontrado a condição padrão para amplificação da região correspondente ao gene da FMN. Utilizando-se a condição padrão e a linhagem de $S$. albus como DNA genômico padrão positivo para a reação encontrou-se 3 linhagens promissoras de produção de poliéteres ionóforos.

\section{Agradecimentos}

PIBIC-CNPq, IQ-UNICAMP, FAPESP

\footnotetext{
Cruz, P. L. Dissertação de mestrado, 2010, Instituto de Química,

Sharma, D. A.; Singh, J.; Notes \& Tips/ Anal. Biochem., 2005, 337, 354-356.

Jiang, C.; Wang, Hougen.; Kang, Q.; Liu, J.; Bai, L. Cloning and Characterization of the Polyether Salinomycin Biosynthesis Gene Cluster of Streptomyces albus XM211, App1 Environ Microbiol. 2012, 78, 994-1003.
} 